\title{
Aplikasi Analisis Kondisi Kesehatan Koperasi pada KSU Sedhana Wiguna Werdhi Berbasis Website
}

\author{
NI LUH KARTIKA DEWI, I MADE DWI PUTRA ASANA, NI PUTU SUCI \\ MEINARNI
}

\author{
Program Studi Teknik Informatika, STMIK STIKOM, Indonesia \\ Email: kartikadewi5697@gmail.com
}

Received 8 April 2021 | Revised 22 Mei 2021 | Accepted 26 Juni 2021

\begin{abstract}
ABSTRAK
Kegiatan operasional pada KSU Sedhana Wiguna Werdhi sudah menggunakan sistem informasi berbasis website, namun terjadi kendala saat koperasi ingin mengetahui gambaran mengenai kondisi kesehatan koperasinya. Selain itu koperasi juga ingin tahu cara untuk mempertahankan atau meningkatkan predikat kesehatan koperasinya. Oleh karena itu, koperasi membutuhkan sistem yang dapat memberikan sebuah gambaran mengenai kondisi kesehatan koperasi. Adapun hasil akhir dari penelitian ini untuk membangun sebuah aplikasi analisis kondisi kesehatan koperasi berbasis website yang dapat membantu manajemen koperasi dalam memberikan gambaran mengenai predikat kesehatan koperasinya dan memberikan gambaran tindakan yang harus dilakukan untuk mempertahankan atau meningkatkan predikat kesehatan koperasinya berdasarkan Peraturan Deputi Bidang Pengawasan Kementrian Koperasi dan Usaha Kecil dan Menengah Republik Indonesia Nomor 06/Per/Dep.6/IV/2016 tentang pedoman penilaian kesehatan koperasi simpan pinjam dan unit usaha simpan pinjam koperasi.
\end{abstract}

Kata kunci: sistem penilaian koperasi, kesehatan koperasi, 7 aspek.

\begin{abstract}
Operational activities at KSU Sedhana Wiguna Werdhi already use a computerized system using a website system. However, they have a problem how to get the health representation. Also KSU Sedhana Wiguna Werdhi did not know what they should to do to maintain or upgrade their predicate of health. Based on the problems, the solution is build a systems that will helped the cooperation to give a health valuation representation of the cooperative. The final results of this research is build a cooperative health condition analysis application. This systems will helped the cooperation to give a health valuation representation of the cooperative and also give a suggestions for maintain or upgrade their predicate of health representation according to government regulation number 06 / Per / Dep.6 / IV / 2016.
\end{abstract}

Keywords: cooperatives valuation system, cooperations health, 7 aspects. 


\section{PENDAhUlUAN}

Koperasi harus melakukan penilaian kesehatan untuk mengetahui gambaran mengenai kesehatan koperasi bagi pihak yang berkepentingan antara lain anggota, pengurus serta pengawas koperasi (Suryanto, Pattiasina \& Soetarmono, 2017). Penilaian kesehatan koperasi akan dilakukan setiap akhir periode atau minimal setahun sekali guna mengetahui prestasi dan keuntungan yang telah dicapai koperasi berdasarkan indikator pengukuran tingkat kesehatan koperasi (Eindrias \& Azizah, 2017). Pertumbuhan aset yang terus berlangsung setiap waktu mengharuskan koperasi untuk melakukan penilaian untuk menjaga kinerja koperasi agar dapat mencapai kesejahteraan anggotanya karena dengan adanya pertumbuhan aset tidak menjamin bahwa kinerja koperasi tersebut bagus (Bhakti, 2018).

Penilaian kesehatan koperasi diperlukan untuk mengawasi serta memperbaiki kualitas dari pihak eksternal maupun pihak internal koperasi. Karena penilaian kesehatan koperasi ini biasanya dilakukan secara manual, hal ini tentunya dapat menghambat pengambilan keputusan. Penilaian ini nantinya akan menjadi acuan masyarakat dalam memberikan kepercayaan terhadap koperasi (Anugrah, 2016).

Manajemen koperasi telah menyusun standar operasional prosedur yang sesuai dengan karakteristik koperasi agar sesuai dengan jati diri koperasi tersebut. Dalam menjalankan usahanya, beberapa koperasi biasanya telah dilengkapi oleh sistem informasi untuk menjalankan standar operasionalnya seperti untuk mencatat simpanan nasabah atau mencatat pinjaman kredit sampai menghasilkan laporan keuangan. Namun, di dalam sistem informasi tersebut belum tentu terdapat informasi tentang penilaian-penilaian untuk menganalisa tingkat kesehatan koperasi pada periode tertentu terhadap kinerja koperasi yang sedang berjalan sehingga diperlukan adanya penambahan fitur dukungan untuk menganalisa kesehatan koperasi tersebut.

Proses penilaian pada KSU Sedhana Wiguna Werdhi dilakukan oleh dinas koperasi terkait, dimana tim dari dinas datang untuk observasi dan meminta dokumen-dokumen yang diperlukan seperti laporan keuangan dan dokumen pendukung lainnya. Setelah diperiksa ternyata koperasi tidak memiliki beberapa dokumen yang dibutuhkan padahal ini berpengaruh terhadap penilaian. Setelah dokumen yang tersedia diserahkan, manajemen harus menunggu informasi dari dinas untuk mengetahui kesehatan koperasinya jadi tidak adanya gambaran mengenai kondisi kesehatan koperasi yang sedang berjalan saat itu. Saat mencoba menghitung secara manual atau menggunakan excel membutuhkan waktu yang cukup lama karena komponen penghitungan dari penilaian ini yang cukup banyak. Selain itu koperasi tidak tahu hal yang harus dilakukan untuk mempertahankan predikatnya atau memperbaiki aspek-aspek terkait penilaian untuk meningkatkan predikat kesehatan koperasi.

Penilaian kondisi kesehatan koperasi berlandaskan pada Peraturan Deputi Bidang Pengawasan Kementrian Koperasi dan Usaha Kecil dan Menengah Republik Indonesia Nomor 06 / Per / Dep.6 / IV / 2016 tentang pedoman penilaian kesehatan koperasi simpan pinjam dan unit usaha simpan pinjam koperasi. Dimana terdapat tujuh aspek penilaian yakni aspek permodalan, aspek kualitas aktiva produktif, aspek manajemen, aspek efisiensi, aspek likuiditas, aspek kemandirian dan pertumbuhan, serta aspek jati diri koperasi (Munir \& Indarti, 2012). Penilain ini nantinya akan memberikan manfaat bagi koperasi untuk mengetahui bagaimana kinerja koperasi berjalan dan prestasi apa saja yang telah dicapai oleh koperasi (Retno, 2013).

Oleh karena itu, untuk membantu manajemen koperasi dalam melakukan penilaian dan memberikan gambaran awal mengenai kondisi kesehatan koperasi serta untuk memberikan 
solusi untuk pengambilan keputusan maka dibutuhkan infrastruktur pendukung berupa sebuah aplikasi untuk membantu menganalisa kondisi kesehatan pada koperasi ini. Atas dasar uraian tersebut, maka dapat dirumuskan sebuah solusi untuk mendesain dan membangun sebuah aplikasi analisis kondisi kesehatan koperasi berbasis website yang dapat memberikan informasi gambaran awal tentang kesehatan koperasi dan koperasi memiliki gambaran untuk memperbaiki atau mempertahankan kinerjanya dalam proses tahun berjalan saat ini.

\section{METODE PENELITIAN}

\subsection{Analisis Perencanaan Sistem}

Tahap-tahap perencanaan pengembangan aplikasi analisis kesehatan koperasi diuraikan pada Tabel 1 berikut.

Tabel 1. Analisis Perencanaan Sistem

\begin{tabular}{|c|c|l|}
\hline No & Tahap & \multicolumn{1}{c|}{ Keterangan } \\
\hline 1. & $\begin{array}{c}\text { Pengumpulan } \\
\text { data }\end{array}$ & $\begin{array}{l}\text { Menggali dan mengumpulkan data apa saja yang akan digunakan dalam } \\
\text { perancangan sistem. }\end{array}$ \\
\hline 2. & Perancangan & Membuat perancangan aplikasi analisis kondisi kesehatan koperasi \\
\hline 3. & Prototyping & Membuat prototype aplikasi analisis kondisi kesehatan koperasi \\
\hline 4. & Evaluasi & Melakukan evaluasi pada prototype analisis kondisi kesehatan koperasi \\
\hline 5. & $\begin{array}{c}\text { Pembuatan } \\
\text { Sistem }\end{array}$ & $\begin{array}{l}\text { Menterjemahkan rancangan sistem (prototype) ke dalam bahasa } \\
\text { pemrograman PHP }\end{array}$ \\
\hline
\end{tabular}

\subsection{Penilaian Kesehatan Koperasi}

Penilaian Kesehatan Koperasi merupakan acuan untuk menentukan kondisi atau keadaan Koperasi Simpan Pinjam atau Unit Simpan Pinjam apakah koperasi tersebut dinyatakan sehat, cukup sehat, kurang sehat, tidak sehat dan sangat tidak sehat pada periode tertentu (Fikar, 2020). Tingkat Kesehatan Koperasi dinilai dengan beberapa indikator atau aspek berdasarkan Undang-Undang. Undang-Undang yang menjadi dasar penilaian ini adalah Peraturan Deputi Bidang Pengawasan Kementrian Koperasi dan Usaha Kecil dan Menengah Republik Indonesia Nomor 06/Per/Dep.6/IV/2016 tentang pedoman penilaian kesehatan koperasi simpan pinjam dan unit usaha simpan pinjam koperasi.

Penilaian untuk setip aspek dilakukan dengan memberikan skor yang nantinya akan mendapat bobot sesuai kriteria yang ditentukan. Beberapa aspek yang tidak dapat dikuantifikasi namun memiliki pengaruh besar akan dianalis dan diuji komponennya. Setelah itu tingkat kesehatan koperasi akan dinyatakan dalam predikat sehat, cukup sehat, kurang sehat, tidak sehat dan sangat tidak sehat (Tyas, 2013). Penetapan predikat tingkat kesehatan KSP / USP koperasi diuraikan pada Tabel 2.

Tabel 2. Penetapan Predikat tingkat kesehatan KSP / USP Koperasi

\begin{tabular}{|c|c|}
\hline Skor & Predikat \\
\hline $80 \leq \mathrm{x}<100$ & Sehat \\
\hline $60 \leq \mathrm{x}<80$ & Cukup Sehat \\
\hline $40 \leq \mathrm{x}<60$ & Kurang Sehat \\
\hline $20 \leq \mathrm{x}<40$ & Tidak Sehat \\
\hline$<20$ & Sangat Tidak sehat \\
\hline
\end{tabular}




\subsection{Bobot Penilaian Aspek Dan Komponen}

Setiap aspek yang dinilai akan diberikan bobot penilaian sesuai dengan seberapa besar pengaruh aspek tersebut terhadap kesehatan koperasi yang dinyatakan dalam angka 0 sampai dengan 100 (Retno $\mathbf{M}$, 2013). Bobot penilaian tersebut diuraikan sebagai berikut.

\subsubsection{Permodalan}

1. Rasio modal sendiri terhadap total aset.

Rasio ini memiliki bobot bernilai 6 .

$$
\frac{\text { Modal Sendiri }}{\text { Total Aset }} \times 100 \%
$$

2. Rasio modal sendiri terhadap pinjaman diberikan yang berisiko. Rasio ini memiliki bobot bernilai 6 .

$$
\frac{\text { Modal Sendiri }}{\text { Pinjaman diberikan berisiko }} \times 100 \%
$$

3. Rasio kecukupan modal sendiri.

Rasio ini memiliki bobot bernilai 3.

$$
\frac{\text { Modal Sendiri Tertimbang }}{\text { ATMR }} \times 100 \%
$$

\subsubsection{Kualitas Aktiva Produktif}

1. Rasio volume pinjaman pada anggota terhadap volume pinjaman diberikan Rasio ini memiliki bobot bernilai 10 .

$$
\frac{\text { Volume Pinjaman Anggota }}{\text { Volume Pinjaman }} \times 100 \%
$$

2. Rasio risiko pinjaman bermasalah terhadap pinjaman yang diberikan. Rasio ini memiliki bobot bernilai 5 .

$$
\frac{\text { Pinjaman Bermasalah }}{\text { Pinjaman Diberikan }} \times 100 \%
$$

3. Rasio cadangan risiko terhadap pinjaman bermasalah. Rasio ini memiliki bobot bernilai 5

$$
\frac{\text { Cadangan Risiko }}{\text { Pinjaman Bermasalah }} \times 100 \%
$$

4. Rasio pinjaman yang berisiko terhadap pinjaman yang diberikan. Rasio ini memiliki bobot bernilai 5

$$
\frac{\text { Pinjaman Berisiko }}{\text { Pinjaman Diberikan }} \times 100 \%
$$

\subsubsection{Manajemen}

Masing-masing rasio memiliki bobot bernilai 3 sehingga bobot maksimal dari aspek manajemen ini bernilai 15

1. Manajemen umum.

2. Manajemen Kelembagaan. 
3. Manajemen Permodalan

4. Manajemen Aktiva

5. Manajemen Likuiditas

\subsubsection{Efisiensi}

1. Rasio beban operasi anggota terhadap partisipasi bruto.

Rasio ini memiliki bobot bernilai 4 .

$$
\frac{\text { Beban Operasi Anggota }}{\text { Partisipasi Bruto }} \text { x 100\% }
$$

2. Rasio beban usaha terhadap SHU Kotor.

Rasio ini memiliki bobot bernilai 4 .

$$
\frac{\text { Beban Usaha }}{\text { SHU Kotor }} \times 100 \%
$$

3. Rasio efisiensi pelayanan.

Rasio ini memiliki bobot bernilai 2 .

$$
\frac{\text { Biaya Karyawan }}{\text { Volume Pinjaman }} \text { x 100\% }
$$

\subsubsection{Likuiditas}

\section{Rasio kas.}

Rasio ini memiliki bobot bernilai 10 .

$$
\frac{\text { Kas+Bank }}{\text { Kewajiban Lancar }} \times 100 \%
$$

2. Rasio pinjaman yang diberikan terhadap dana yang diterima. Rasio ini memiliki bobot bernilai 5 .

$$
\frac{\text { Pinjaman Diberikan }}{\text { Dana yang Diterima }} \times 100 \%
$$

\subsubsection{Kemandirian dan Pertumbuhan}

\section{Rasio Rentabilitas Aset.}

Rasio ini memiliki bobot bernilai 3 .

$$
\frac{\text { SHU Sebelum Pajak }}{\text { Total Aset }} \times 100 \%
$$

2. Rasio Rentabilitas Modal Sendiri.

Rasio ini memiliki bobot bernilai 3 .

$$
\frac{\text { SHU Bagian Anggota }}{\text { Total Aset }} \times 100 \%
$$

3. Rasio Rentabilitas Operasional Pelayanan. Rasio ini memiliki bobot bernilai 4.

$$
\frac{\text { Partisipasi Neto }}{\text { Total Modal Sendiri }} \times 100 \%
$$




\subsubsection{Jati Diri Koperasi}

1. Rasio partisipasi bruto.

Rasio ini memiliki bobot bernilai 7.

$$
\frac{\text { Partisipasi Bruto }}{\text { Partisipasi Bruto+Pendapatan }} \times 100 \%
$$

2. Rasio promosi ekonomi anggota (PEA).

Rasio ini memiliki bobot bernilai 3.

$$
\frac{\text { PEA }}{\text { Simpanan Pokok+Simpanan Wajib }} \times 100 \%
$$

Berdasarkan penghitungan diatas didapatkan hasil dari penghitungan data dan bobot skor yang didapatkan pada setiap aspek yang diuraikan dalam Tabel 3.

\begin{tabular}{|c|c|c|}
\hline No & Aspek & Penilaian Skor \\
\hline \multirow[t]{4}{*}{1} & Permodalan & \\
\hline & Rasio Modal sendiri terhadap total aset & 3,00 \\
\hline & Rasio modal sendiri terhadap pinjaman diberikan yang berisiko & 3,00 \\
\hline & Rasio kecukupan modal sendiri & 3,00 \\
\hline \multirow[t]{5}{*}{2} & Kualitas Aktiva Produktif & \\
\hline & $\begin{array}{l}\text { Rasio volume pinjaman pada anggota terhadap volume pinjaman } \\
\text { diberikan }\end{array}$ & 10,00 \\
\hline & Rasio risiko pinjaman bermasalah terhadap pinjaman yang diberikan & 5,00 \\
\hline & Rasio cadangan risiko terhadap pinjaman bermasalah & 1,00 \\
\hline & Rasio pinjaman yang berisiko terhadap pinjaman yang diberikan & 1,25 \\
\hline \multirow[t]{6}{*}{3} & Manajemen & \\
\hline & Manajemen Umum & 2,50 \\
\hline & Manajemen Kelembagaan & 1,00 \\
\hline & Manajemen Permodalan & 2,40 \\
\hline & Manajemen Aktiva & 1,50 \\
\hline & Manajemen Likuiditas & 1,80 \\
\hline \multirow[t]{4}{*}{4} & Efisiensi & \\
\hline & Rasio beban operasi anggota terhadap partisipasi bruto & 1,00 \\
\hline & Rasio beban usaha terhadap SHU kotor & 1,00 \\
\hline & Rasio efisiensi pelayanan & 2,00 \\
\hline \multirow[t]{3}{*}{5} & Likuiditas & \\
\hline & Rasio Kas & 2,50 \\
\hline & Rasio pinjaman yang diberikan terhadap dana yang diterima & 2,50 \\
\hline \multirow[t]{4}{*}{6} & Kemandirian dan Pertumbuhan & \\
\hline & Rentabilitas asset & 0,75 \\
\hline & Rentabilitas modal sendiri & 3,00 \\
\hline & Kemandirian operasional pelayanan & 0,00 \\
\hline \multirow[t]{4}{*}{7} & Jati diri Koperasi & \\
\hline & Rasio Partisipasi Bruto & 7,00 \\
\hline & Rasio PEA & 3,00 \\
\hline & Jumlah & 58,20 \\
\hline
\end{tabular}

Tabel 3. Hasil Penghitungan Aspek

Jumlah skor hasil penilaian kesehatan KSU Sedhana Wiguna Werdhi adalah 58,20 yang berada pada rentang nilai antara 40 hingga 60, berarti termasuk kriteria kurang sehat. 


\section{HASIL DAN PEMBAHASAN}

\subsection{Gambaran Umum Sistem}

Secara umum, prosedur penggunaan aplikasi analisis kondisi kesehatan koperasi pada KSU Sedhana Wiguna Werdhi dimulai dari admin menambahkankan data penilaian pada sistem yang akan tersimpan di database. Kemudian sistem akan menghitung penilaian berdasarkan data penilaian yang telah ditambahkan. Lalu, sistem akan menampilkan laporan penilaian kondisi kesehatan koperasi.

\subsection{Context Diagram}

Pada Gambar 1 merupakan context diagram untuk aplikasi analisis kondisi kesehatan koperasi pada KSU Sedhana Wiguna Werdhi berbasis website.

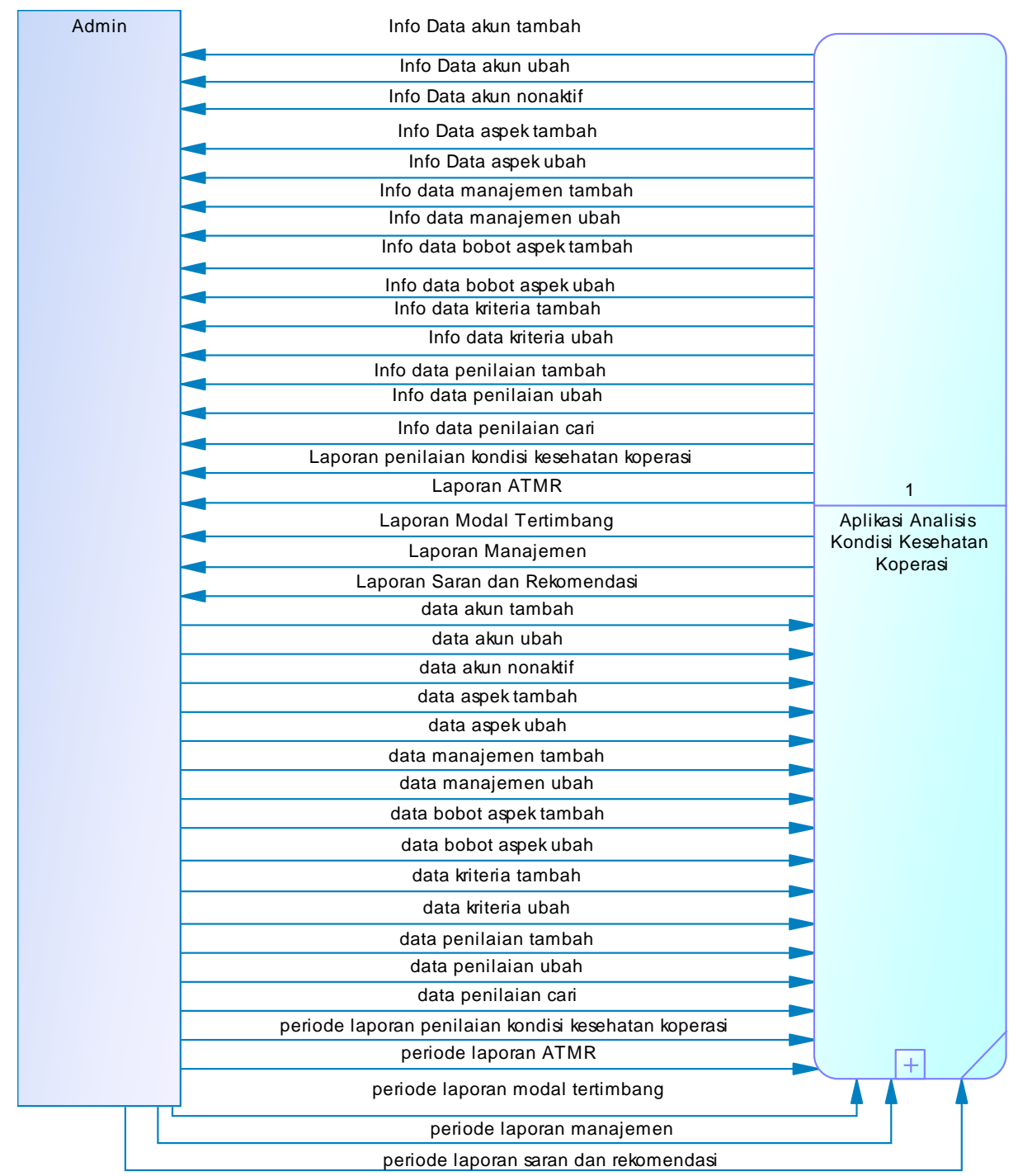

Gambar 1. Context Diagram

\subsection{Conceptual Data Model (CDM)}

Pada Gambar 2 berikut merupakan conceptual data model (CDM) dari aplikasi analisis kondisi kesehatan koperasi pada KSU Sedhana Wiguna Werdhi berbasis website. Terdapat tujuh tabel yaitu tabel penilaian, tabel kriteria, tabel user, tabel aspek, tabel bobot aspek penilaian, tabel akun dan tabel manajemen. 


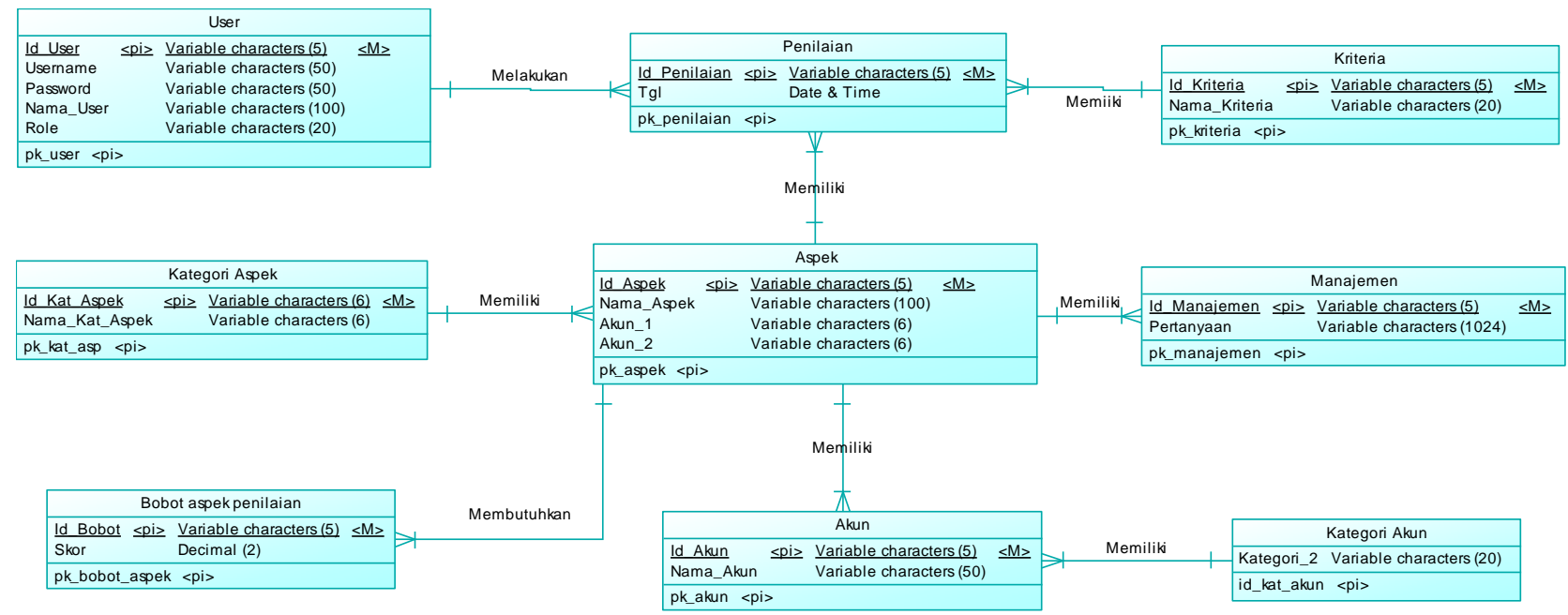

Gambar 2. Conceptual Data Model

\subsection{Tampilan Sistem}

Tampilan sistem digunakan sebagai penghubung antara algoritma pemrograman yang dirancang sedemikian rupa sehingga pengguna dapat menjalankan sistem sesuai dengan fungsinya.

\subsubsection{Halaman Login}

Halaman login merupakan tampilan awal ketika pengguna membuka website. Halaman ini digunakan oleh admin dan pengawas. Pada halaman ini terdapat kotak untuk menambahkan username dan password yang digunakan untuk memasukkan data diri yang telah didaftarkan sebelumnya. Terdapat tombol login yang mengarahkan ke menu beranda sesuai dengan kategori masing-masing user.

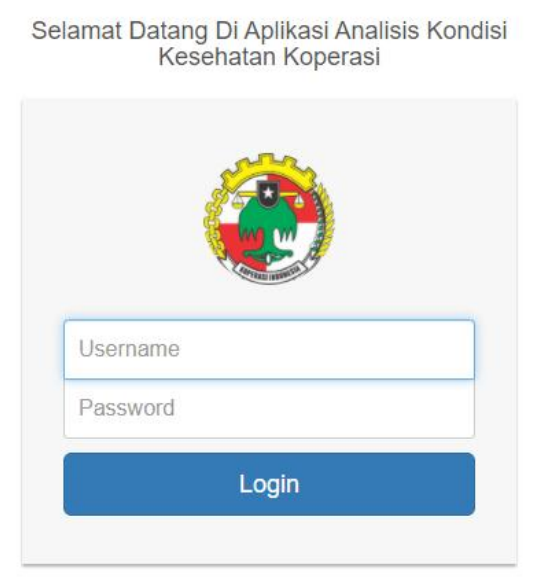

\section{Gambar 3. Halaman Login}

\subsubsection{Halaman Beranda Admin}

Halaman beranda admin terdapat beberapa menu yaitu beranda, input penilaian, laporan dan master data. Pada menu beranda akan menampilkan card yang berisi nama koperasi, kriteria dan skor serta menampilkan grafik perbandingan penilaian kesehatan koperasi setiap periode yang ditambahkan, kemudian pada menu input penilaian terdapat form untuk menambahkan data penilaian seperti laporan neraca, laporan perhitungan SHU, laporan peminjaman dan laporan manajemen, pada menu laporan terdapat laporan seperti laporan penilaian kesehatan koperasi, laporan ATMR, laporan modal tertimbang, serta laporan sesuai dengan data yang dimasukkan di menu input penilaian seperti laporan neraca, laporan 
perhitungan SHU, laporan peminjaman dan laporan manajemen sesuai tanggal yang ditentukan, juga terdapat halaman untuk menampilkan saran dan rekomendasi perbaikan, pada menu master data terdapat data akun, data aspek, data manajemen, data bobot aspek penilaian, data kriteria serta data user.

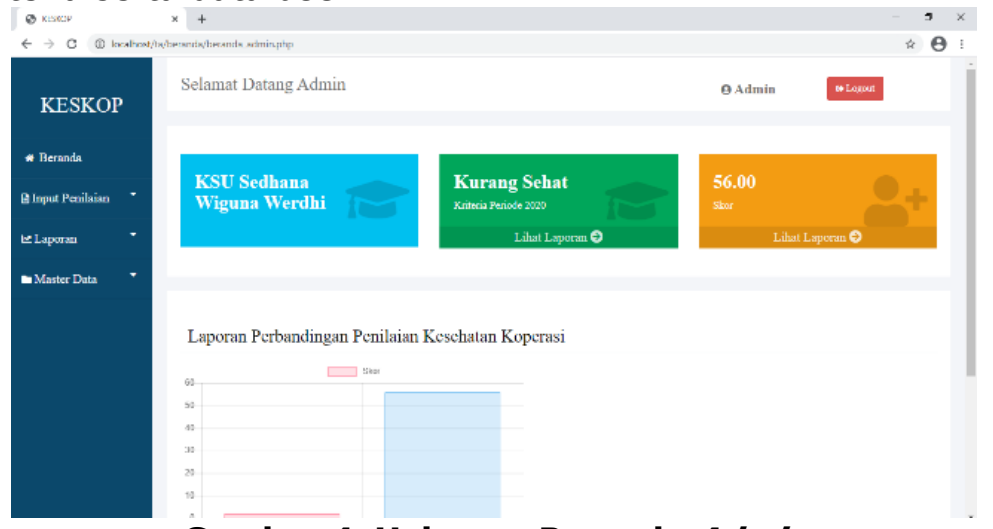

Gambar 4. Halaman Beranda Admin

\subsubsection{Halaman Data Akun}

Halaman data akun digunakan untuk menampilkan data akun pada laporan keuangan koperasi. Jika ingin menambahkan dat akun, maka pengguna dapat menekan tombol tambah akun, terdapat aksi ubah yang digunakan untuk mengubah data akun dan terdapat aksi nonaktifkan akun yang digunakan untuk menonaktifkan akun. Apabila aksi nonaktifkan akun dipilih maka akun yang dinonaktifkan tidak akan terlihat pada halaman data akun. Pada halaman data akun juga menampilkan saldo sesuai tanggal yang dimasukkan pada menu input.

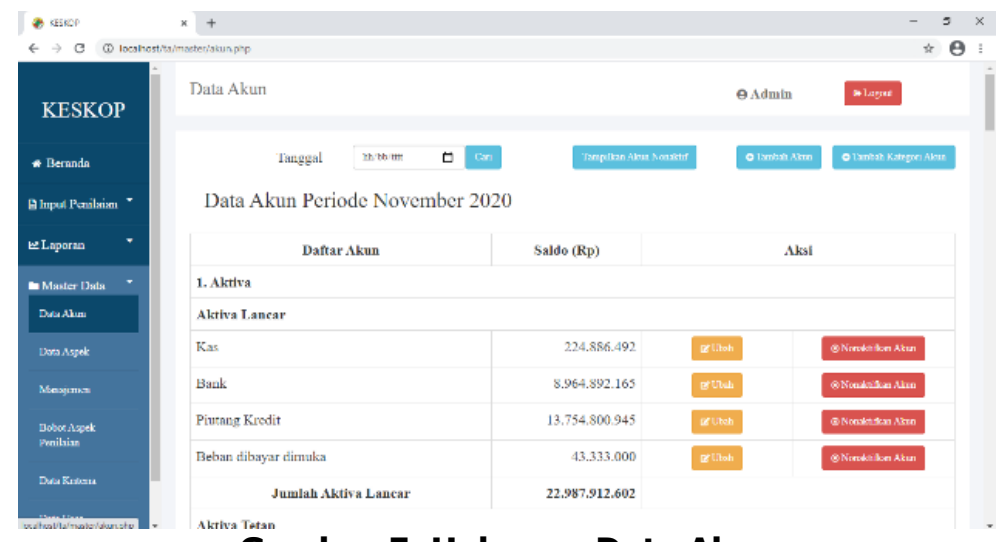

Gambar 5. Halaman Data Akun

\subsubsection{Halaman Input Penilaian Laporan Neraca}

Halaman input penilaian laporan neraca digunakan untuk menambahkan data penilaian nantinya. Pada halaman ini, terdapat tombol untuk menambahkan tanggal, lalu terdapat form untuk menambah saldo pada akun-akun di laporan neraca dan terdapat tombol simpan untuk menambah data penilaian. 


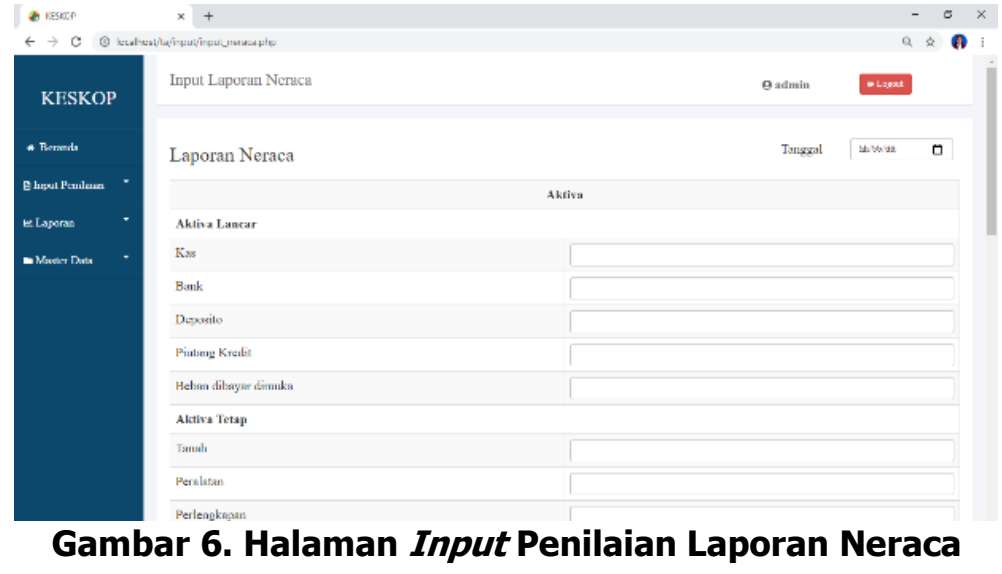

\subsubsection{Halaman Input Penilaian Laporan Perhitungan SHU}

Halaman input penilaian laporan perhitungan SHU digunakan untuk menambahkan data penilaian nantinya. Pada halaman ini, terdapat tombol untuk menambahkan tanggal, lalu terdapat form untuk menambah saldo pada akun-akun di laporan perhitungan SHU. Pada halaman ini terdapat tombol simpan untuk menambah data penilaian dan tombol batal untuk mengosongkan data yang ditambahkan.

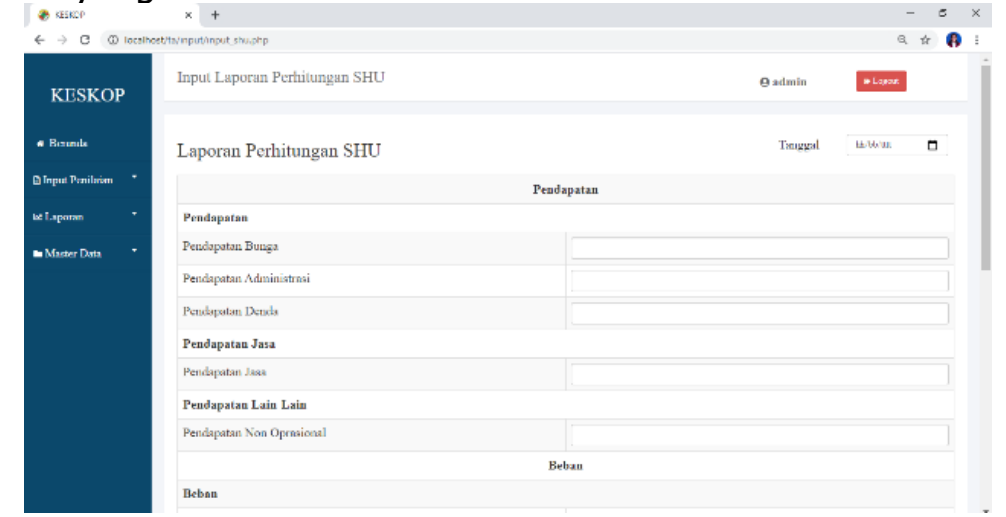

Gambar 7. Halaman Input Penilaian Laporan Perhitungan SHU

\subsubsection{Halaman Input Penilaian Laporan Peminjaman}

Halaman input penilaian laporan peminjaman digunakan untuk menambahkan data penilaian nantinya. Pada halaman ini, terdapat tombol untuk menambahkan tanggal, lalu terdapat form untuk menambah saldo pada akun-akun di laporan peminjaman. Pada halaman ini terdapat tombol simpan untuk menambah data penilaian dan tombol batal untuk mengosongkan data yang ditambahkan.

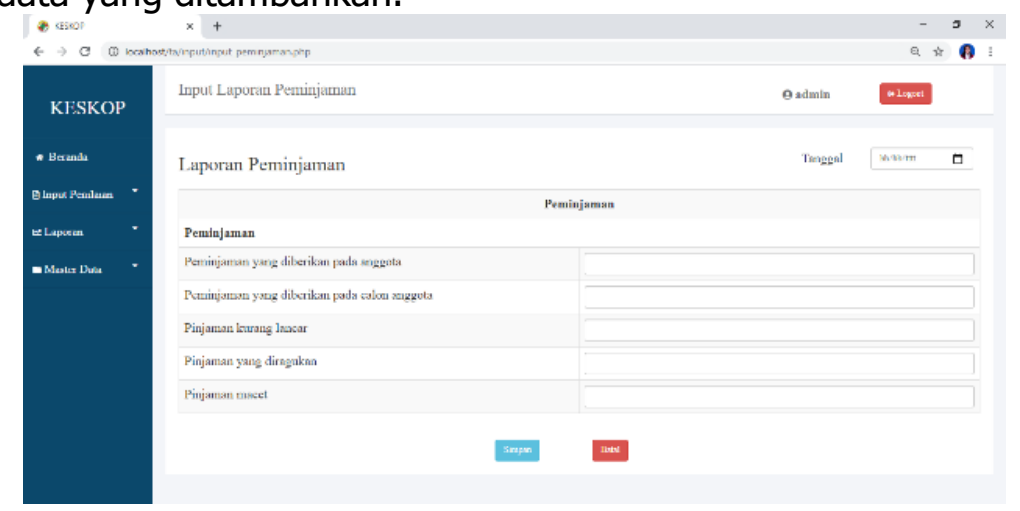

Gambar 8. Halaman Input Penilaian Laporan Peminjaman 


\subsubsection{Halaman Input Penilaian Laporan Manajemen}

Halaman input penilaian manajemen digunakan untuk menambahkan data penilaian nantinya. Pada halaman ini, terdapat tombol untuk menambahkan tanggal, lalu terdapat form untuk memilih jawaban ya atau tidak pada setiap pertanyaan yang ditanyakan. Pada halaman ini terdapat tombol simpan untuk menambah data penilaian dan tombol batal untuk mengosongkan data yang ditambahkan.

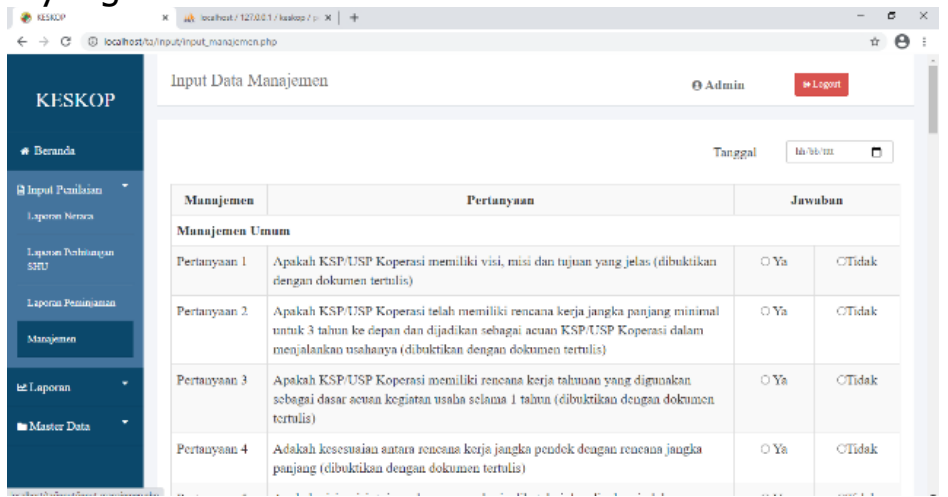

Gambar 9. Halaman Input Penilaian Manajemen

\subsubsection{Halaman Laporan Penilaian Kesehatan Koperasi}

Halaman laporan penilaian kesehatan koperasi digunakan untuk menampilkan laporan penilaian berdasarkan data yang telah ditambahkan sesuai periode yang ditentukan. Laporan ini nantinya akan memberikan informasi predikat koperasi sesuai periode yang dipilih. User dapat memilih periode penilaian dan terdapat tombol cetak untuk mencetak laporan.

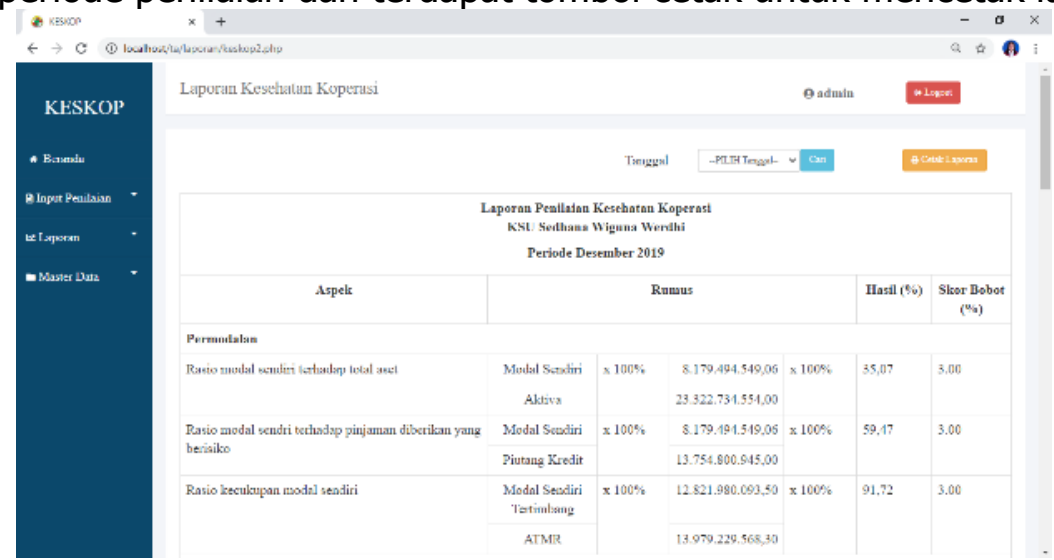

Gambar 10. Halaman Laporan Penilaian Kesehatan Koperasi

\subsubsection{Halaman Laporan ATMR}

Halaman laporan Aktiva Tertimbang Menurut Rasio (ATMR) digunakan untuk menampilkan laporan ATMR berdasarkan data yang telah ditambahkan sesuai periode yang ditentukan. Laporan ini digunakan untuk mengetahui seberapa besar risiko keuangan koperasi berdasarkan pengelolaan asetnya. User dapat memilih periode laporan dan terdapat tombol cetak untuk mencetak laporan. 


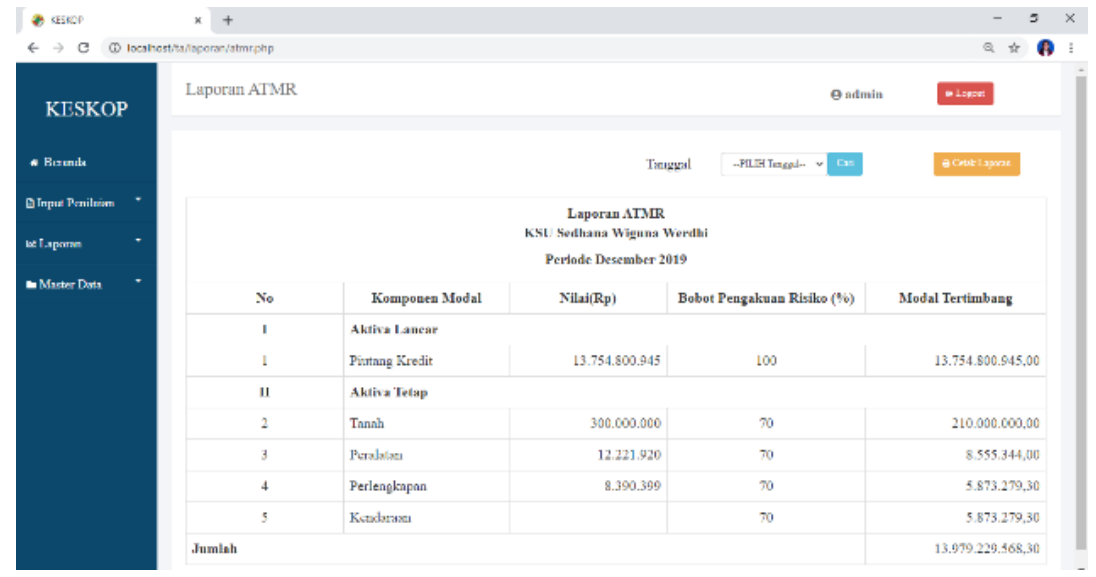

Gambar 11. Halaman Laporan ATMR

\subsubsection{Halaman Laporan Modal Tertimbang}

Halaman laporan modal tertimbang digunakan untuk menampilkan laporan modal tertimbang berdasarkan data yang telah ditambahkan sesuai periode yang ditentukan. Laporan ini akan memberikan informasi seberapa besar risiko modal koperasi terhadap hutang yang dimiliki. User dapat memilih periode laporan dan terdapat tombol cetak untuk mencetak laporan.

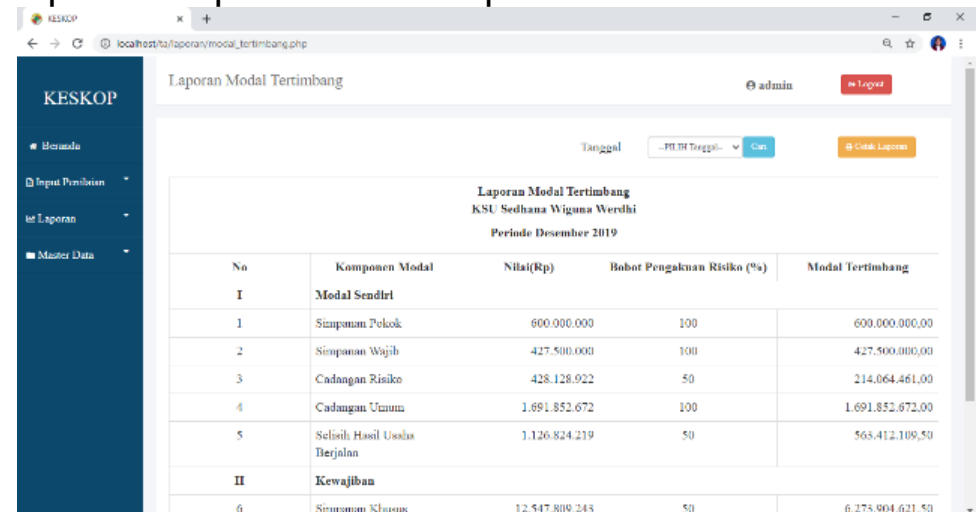

Gambar 12. Halaman Laporan Modal Tertimbang

\subsubsection{Halaman Laporan Manajemen}

Halaman laporan peminjaman digunakan untuk menampilkan laporan manajemen berdasarkan data yang telah ditambahkan sesuai periode yang ditentukan. Laporan ini digunakan untuk menampilkan jawaban dari pertanyaan setiap aspek pada periode yang dipilih.

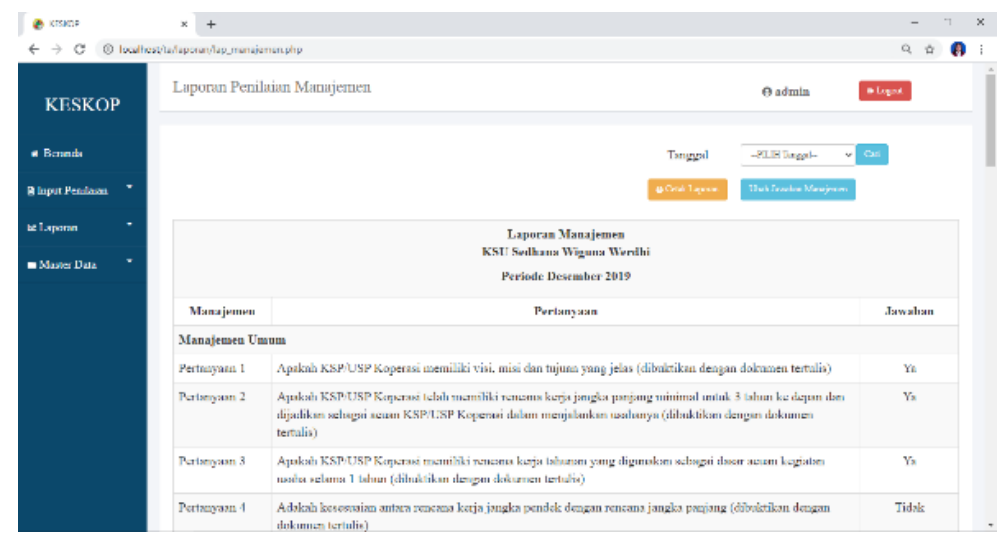

Gambar 13. Halaman Laporan Manajemen 


\subsubsection{Halaman Saran Dan Rekomendasi}

Halaman saran dan rekomendasi digunakan untuk menampilkan laporan kesehatan koperasi berdasarkan data yang telah ditambahkan sesuai periode yang ditentukan. Laporan ini digunakan untuk menampilkan saran dan rekomendasi perbaikan dari setiap aspek penilaian yang dapat digunakan oleh pengurus koperasi dalam memperbaiki aspek-aspek yang belum maksimal.

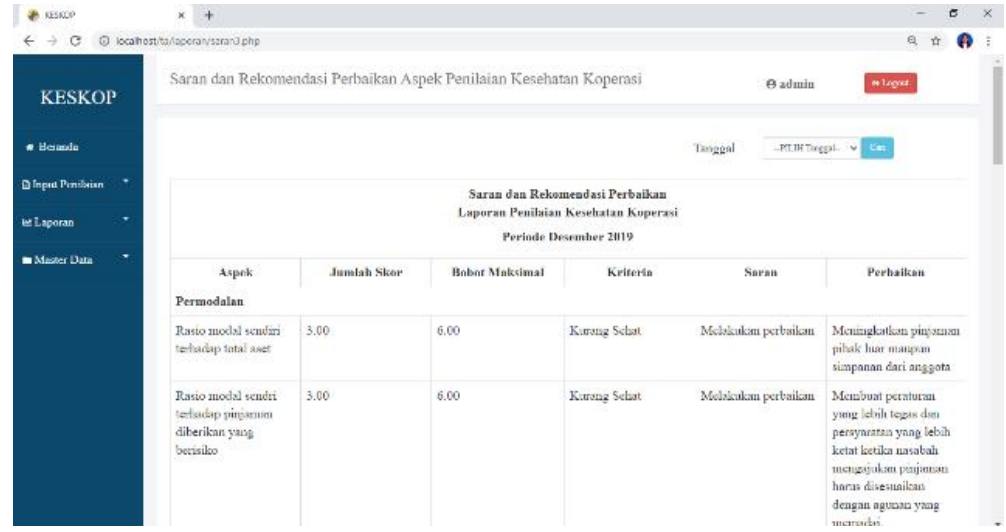

Gambar 14. Halaman Saran dan Rekomendasi

\section{KESIMPULAN}

Fitur-fitur yang dibangun telah sesuai dengan rancangan dan dapat berjalan dengan baik telah mampu memberikan penilaian mengenai tingkat kesehatan koperasi serta dapat memberikan saran dan rekomendasi perbaikan untuk skor bobot aspek yang masih belum mencapai kriteria sehat dengan bobot $100 \%$.

\section{DAFTAR RUJUKAN}

Anugrah, A. A. (2016). Dashboard Information System Penilaian Predikat Kesehatan Koperasi Simpan Pinjam ( KSP) dan Unit Simpan Pinjam ( USP) Berbasis Web Menggunakan Metode Profile Matching.

Bhakti, T. H. (2018). Analisis Kesehatan Koperasi Berdasarkan Peraturan Menteri Negara Koperasi Dan Usaha Kecil Dan Menengah Republik Indonesia Nomor: 14 /Per / M.KUKM /XII / 2009 (Studi Pada KSP Setia Bhakti Kota Kediri Periode 2013-2015), 63(14), 130-139.

Eindrias, T. D., \& Azizah, D. F. (2017). Analisa Tingkat Kesehatan Koperasi Simpan Pinjam Berdasarkan Peraturan Nomor: 06/PER/DEP.6/IV/2016(Studi Pada Koperasi Simpan Pinjam Bahagia Kediri). Jurnal Administrasi Bisnis, 51(2), 135-140.

Fikar, S. (2020). Analisis Tingkat Kesehatan Koperasi Simpan Pinjam : Studi Kasus pada Koperasi Trimitra. Undergraduate thesis, Universitas Islam Negeri Maulana Malik Ibrahim.

Munir, M., \& Indarti, I. (2012). Analisis Tingkat Kesehatan Koperasi pada Koperasi Simpan Pinjam "Cendrawasih" Kecamatan Grubug Tahun Buku 2011. 
Aplikasi Analisis Kondisi Kesehatan Koperasi pada KSU Sedhana Wiguna Werdhi Berbasis Website

Peraturan Deputi Bidang Pengawasan Kementrian Koperasi dan Usaha Kecil dan Menengah Republik Indonesia Nomor 06/Per/Dep.6/IV/2016 tentang pedoman penilaian kesehatan koperasi simpan pinjam dan unit usaha simpan pinjam koperasi.

Retno, F., M. (2013). Analisis Tingkat Kesehatan Koperasi Simpan Pinjam atau Unit Usaha Simpan Pinjam Koperasi di Kota Surakarta. Universitas Muhammadiyah Surakarta.

Surakarta: Fakultas Ekonomi dan Bisnis Jurusan Akuntansi Universitas Muhammadiyah.

Suryanto, S. P., Pattiasina, T. J., \& Soetarmono, A. (2017). Perancangan dan Pengembangan Toko Online dengan Metode Interaction Flow Modeling Language (Studi Kasus Toko Winata), Teknika, 6(1), 7-18.

Tyas, L. H. (2013). Rancang bangun sistem informasi penilaian kesehatan koperasi pada Koperasi Simpan Pinjam Mitra Mandiri Lamongan: Aspek likuiditas, kemandirian dan pertumbuhan. Undergraduate thesis, Universitas Islam Negeri Maulana Malik Ibrahim. Undang-Undang Republik Indonesia Nomor 17 Tahun 2012 Tentang Perkoperasian. 